\title{
Conceptualizing humans as animals in English verb particle constructions
}

\author{
Klaus-Uwe Panther \\ panther@uni-hamburg.de \\ Nanjing Normal University, China, and University of Hamburg, Germany \\ Linda L. Thornburg \\ lthornburg@alumni.usc.edu \\ Nanjing Normal University, China
}

\begin{abstract}
Verb particle constructions with animal names used as verbs ('VPrt critter constructions'), such as horse around, clam up, and rat out, are interesting because of their (i) grammatical structure, (ii) pragmatic function, (iii) conceptual content, and (iv) the cultural knowledge they reflect. This chapter focuses on the latter two aspects of critter constructions. More specifically, we assume that an adequate analysis of critter constructions requires folk or cultural models of the animals in question, spatial schemas for the particle, metaphorical mappings and metonymic inferences, and aspectual categories in the sense of Vendler (1957). We place our findings in the larger context of the status of cultural and cognitive models in general. Such models (including animal folk models) are often outdated and reflect centuries-old beliefs that have left their traces in lexico-grammatical structure, in this case, critter constructions.
\end{abstract}

Keywords: aspect, critter construction, cultural model, metaphor, metonymy, noun-verb conversion

\section{INTRODUCTION}

The conceptualization of humans and even divinities in terms of animals is a plausible candidate for a cultural universal. In many cultures, e.g. in ancient Egypt, gods and goddesses were pictorially and sculpturally represented as animals (or hybrids of humans and animals) such as falcons, cows, rams, lions, and crocodiles. Their visual representation as animals does not mean that they were categorized as animals but that they possessed certain characteristics rightly or wrongly attributed to the animals in question (Ris-Eberle 2004: 50).

Goatly (2006: 32) distinguishes among three interpretations of the formula HUMAN IS ANIMAL. It may be a statement of hyponymy, i.e. 'a human is a kind of animal', one of near-identity, i.e. 'humans are more or less like animals', or a metaphor, i.e. 'humans are like animals'. The metaphoric interpretation presupposes similarity but also 
distinctness of conceptual domains. It entails that humans are essentially different from animals; otherwise, it would make no sense to assume cross-domain mappings linking presumed animal properties with human characteristics. In the Western Judeo-Christian tradition, on which many folk models of animals are at least partially based, animals are indeed - in contrast to humans - typically regarded as lacking a soul or lacking reason. This conception is still found in the $17^{\text {th }}$ century in Descartes' Discours de la méthode, where it is claimed that animals have no "âme raisonnable" and are ontologically comparable to clockworks (horloges) (Bridoux 1953: 166).

In the domain of literature, animals occupy a prominent position, e.g. in fables, a genre that, in the Western tradition, goes back at least to the Greek poet Aesop ( $6^{\text {th }}$ century B.C.). Fables are usually short narratives with animal characters that end with a moral lesson for humans. Jean de La Fontaine (1621-1695) is often praised as "the greatest of all modern fable writers" (Drabble 2000: 344), and his second fable Le corbeau et le renard (English translation by Elizur Wright (1804-1885)) is a prime example of the narrative structure of fables and the moral lessons they convey: ${ }^{1}$

Le corbeau et le renard

Maître corbeau, sur un arbre perché,

Tenait en son bec un fromage.

Maître renard, par l'odeur alléché.

Lui tint à peu près ce langage:

« Hé! bonjour, monsieur du corbeau.

Que vous êtes joli! que vous me semblez beau!

Sans mentir, si votre ramage.

Se rapporte à votre plumage,

Vous êtes le phénix des hôtes de ces bois. »

A ces mots le corbeau ne se sent pas de joie,

Et, pour montrer sa belle voix,

Il ouvre un large bec, laisse tomber sa proie.

Le renard s'en saisit, et dit:

« Mon bon monsieur, Apprenez que tout flatteur

Vit aux dépens de celui qui l'écoute.

Cette leçon vaut bien un fromage, sans doute. »

Le corbeau, honteux et confus,

Jura, mais un peu tard, qu'on ne l'y prendrait plus.
The raven and the fox

Perch'd on a lofty oak,

Sir Raven held a lunch of cheese;

Sir Fox, who smelt it in the breeze,

Thus to the holder spoke: -

"Ha! how do you do, Sir Raven?

Well, your coat, sir, is a brave one!

So black and glossy, on my word, sir,

With voice to match, you were a bird, sir,

Well fit to be the Phoenix of these days."

Sir Raven, overset with praise,

Must show how musical his croak.

Down fell the luncheon from the oak;

Which snatching up, Sir Fox thus spoke:-

"The flatterer, my good sir,

Aye liveth on his listener;

Which lesson, if you please,

Is doubtless worth the cheese."

A bit too late, Sir Raven swore

The rogue should never cheat him more.

\footnotetext{
1 The source of the original fable, the English translation, and the illustration is: http://chefdoeuvre.blogspot.com/2007/04/le-corbeau-et-le-renard.html (accessed December 27, 2011).
} 


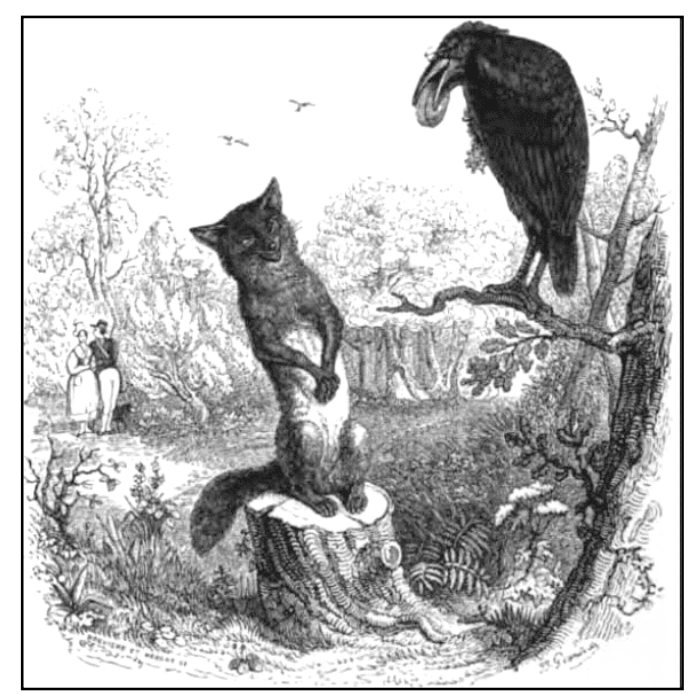

Figure 1. The sly fox “outfoxes” the raven.

The fox is a skilled rhetorician, who showers the raven with insincere and excessive praise and as a result of his cunning gets the desired cheese. Despite this unfortunate outcome for the raven, the bird grasps the moral lesson 'Never trust a flatterer' and vows to adjust his future behavior accordingly. The moral lesson easily transfers to human affairs and it is describable in terms of metaphorical mappings from the animal domain into the human domain (see section III). The interpretation of the fable draws heavily on a folk model or cultural model of foxes. In a nutshell, this cultural model is captured and evoked in expressions such as sly fox and verbs such as to fox or to outfox (see Figure 1).

The present chapter is concerned with a subclass of verb-particle (VPrt) constructions, such as rat out, beaver away, and horse around that reflect "frozen" cultural models, in the sense described in the preceding paragraph. These constructions consist of a verb converted from an animal noun and a particle, which, in its source sense, denotes a spatial schema that is metonymically linked to an aspectual target sense. ${ }^{2}$ In what follows we use the term 'critter constructions' as shorthand for 'VPrt critter constructions'.

To conclude this part of the discussion, we claim that diverse phenomena like religious and philosophical schools of thinking, literary genres, and, on a micro-level, lexico-

\footnotetext{
${ }^{2}$ Related to VPrt critter constructions are critter constructions with a preposition (e.g. rat on 'inform on') and transitive critter constructions (e.g. fox $s b$. 'deceive, baffle'); these are not considered in the present chapter.
} 
grammatical codings such as critter constructions have more in common than meets the eye. Indeed, a deeper understanding of their meaning has to be sought in the larger context of human thinking (cognition), and how it relates to culture and language. Figure 2 is an attempt to diagram some aspects of this relationship.

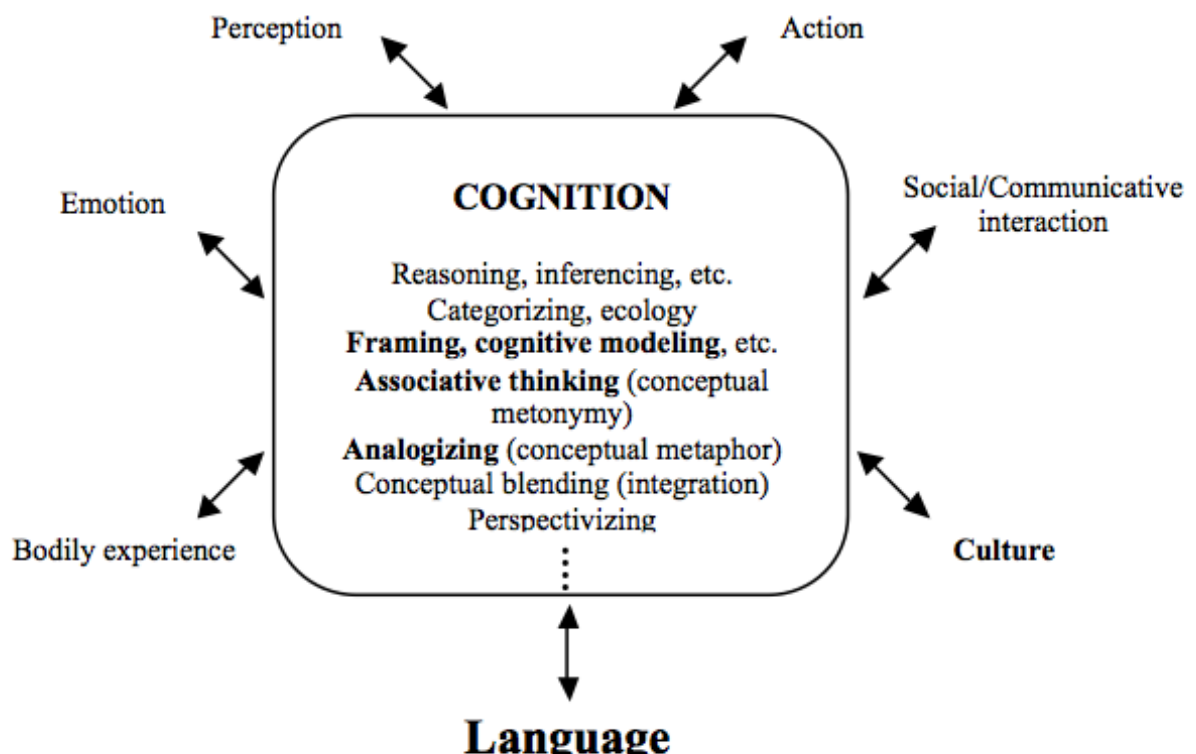

Figure 2. Language and cognition (adapted from Panther and Radden 2011: 2)

Following Panther and Radden (2011), cognition is here understood as a cover term for the higher human faculties of reasoning, e.g. drawing inferences, constructing and interpreting cognitive models, linking concepts associatively (metonymy), and drawing analogies between distinct conceptual domains (metaphor). These faculties interact with 'peripheral' systems such as emotion, bodily experience, perception, action, culture, social interaction, and language.

Our understanding of the notion of cultural model, which we use interchangeably with the term 'folk model’ in this chapter, follows Quinn and Holland (1987: 4):

Cultural models are presupposed, taken-for-granted models of the world that are widely shared (although not necessarily to the exclusion of other, alternative models) by the members of a society and that play an enormous role in their understanding of that world and their behavior in it.

This chapter is organized as follows. In section II we briefly note the use and the meaning of animal terms in a variety of lexico-grammatical constructions. Section III 
investigates the semantics of critter constructions in more detail. Section IV summarizes the results and concludes with some reflections on folk models and linguistic coding.

\section{SOME CONSTRUCTIONS INVOLVING ANIMAL TERMS}

Given the hypothesized universal that humans are conceptualized or represented as animals, it does not come as a surprise that animal terms are in fact used in various lexical, morphological, and syntactic environments:

$$
\text { John really made a pig of himself at the party. (LDAE) (lexical construction) }
$$$$
\text { John is a pig. (predicate nominal construction) }
$$$$
\text { You pig! (epithet construction) }
$$

She is pig-headed. (compound construction)

It is the type of construction illustrated in (5) that is examined in more detail in section III. One important fact about the use of pig in sentences (1)-(5) is that its respective meanings vary from context to context. While pig in (1) and (5) may refer to a person who overindulges in food, in (2) and (3) pig could be interpreted as a despicable person holding sexist or racist views, and in (4), according to the New Oxford American Dictionary, pig-headed means 'stupidly obstinate'. Similarly, while a critter construction like monkey around means 'behave in a silly and playful way', the prepositional verb monkey with has the sense 'to touch, use, or examine [...] without skill and so possibly causing damage’ (LDAE).

The lesson to be learned from examples (1)-(5) and the various uses of monkey as a verb is that the figurative meanings of animal terms are not predictable but rather are context- and construction-specific. However, non-predictability does not entail 'arbitrariness'. Indeed, we claim that the use of animal terms as verbs is motivated, in that it can be traced back to a folk model of the animal in question, from which certain components are selected and eventually end up as conventionalized senses in individual constructions. 


\section{CRITTER CONSTRUCTIONS IN ENGLISH}

To begin, critter constructions tend not to be used literally, due to a principle of redundancy avoidance. Formulations such as *The squirrel squirreled away some acorns, *Those pigs are pigging out again today, and *Don't let that cat cat around! are infelicitous. ${ }^{3}$ Moreover, critter constructions seem to be more frequent in English as compared to languages like German and French. Table 1 lists a number of such constructions (in alphabetical order), commonly found in English, and their translations into German and French.

Table 1. Some critter constructions in English and their equivalents in German and French.*

\begin{tabular}{|c|c|c|c|c|}
\hline & ANIMAL & ENGLISH & GERMAN & FRENCH \\
\hline $\begin{array}{l}\text { Eng } \\
\text { Ger } \\
\text { Fr } \\
\end{array}$ & $\begin{array}{l}\text { beaver } \\
\text { Biber } \\
\text { castor }\end{array}$ & beaver away (at) & schuften & $\begin{array}{l}\text { travailler d'arrache } \\
\text { pied }\end{array}$ \\
\hline $\begin{array}{l}\text { Eng } \\
\text { Ger } \\
\text { Fr }\end{array}$ & $\begin{array}{l}\text { Cat } \\
\text { Katze } \\
\text { chat }\end{array}$ & cat about/around & herumtreiben, anmachen & draguer \\
\hline $\begin{array}{l}\text { Eng } \\
\text { Ger } \\
\text { Fr }\end{array}$ & $\begin{array}{l}\text { chicken } \\
\text { Küken } \\
\text { poulet }\end{array}$ & chicken out & kneifen, aussteigen & se dégonfler \\
\hline $\begin{array}{l}\text { Eng } \\
\text { Ger } \\
\text { Fr }\end{array}$ & $\begin{array}{l}\text { clam } \\
\text { Muschel } \\
\text { moule }\end{array}$ & clam up & keinen Piep mehr sagen & ne plus piper mot \\
\hline $\begin{array}{l}\text { Eng } \\
\text { Ger } \\
\text { Fr } \\
\end{array}$ & $\begin{array}{l}\text { ferret } \\
\text { Frettchen } \\
\text { furet } \\
\end{array}$ & $\begin{array}{l}\text { ferret about } \\
\text { ferret out }\end{array}$ & $\begin{array}{l}\text { herumstöbern } \\
\text { jm. aufspüren }\end{array}$ & $\begin{array}{l}\text { fureter (dans) } \\
\text { découvrir, dénicher }\end{array}$ \\
\hline $\begin{array}{l}\text { Eng } \\
\text { Ger } \\
\text { Fr }\end{array}$ & $\begin{array}{l}\text { fish } \\
\text { Fisch } \\
\text { poisson }\end{array}$ & $\begin{array}{l}\text { fish around (for) } \\
\text { fish out sb. }\end{array}$ & $\begin{array}{l}\text { kramen (nach) etw. } \\
\text { etw. herausholen }\end{array}$ & $\begin{array}{l}\text { farfouiller } \\
\text { sortir qch. de }\end{array}$ \\
\hline $\begin{array}{l}\text { Eng } \\
\text { Ger } \\
\text { Fr } \\
\end{array}$ & $\begin{array}{l}\text { fox } \\
\text { Fuchs } \\
\text { renard }\end{array}$ & fox sb. out (of) & $\begin{array}{l}\text { jm. täuschen, jm. } \\
\text { hereinlegen }\end{array}$ & $\begin{array}{l}\text { dérouter, } \\
\text { désarçonner qn. }\end{array}$ \\
\hline $\begin{array}{l}\text { Eng } \\
\text { Ger } \\
\text { Fr }\end{array}$ & $\begin{array}{l}\text { horse } \\
\text { Pferd } \\
\text { cheval }\end{array}$ & horse around/ about & herumalbern & chahuter \\
\hline $\begin{array}{l}\text { Eng } \\
\text { Ger } \\
\text { Fr } \\
\end{array}$ & $\begin{array}{l}\text { hound } \\
\text { Jagdhund } \\
\text { chien de chasse }\end{array}$ & $\begin{array}{l}\text { hound sb. out (of) } \\
\text { hound sb. down }\end{array}$ & $\begin{array}{l}\text { jm. hinausjagen, vertreiben } \\
\text { jm. zur Strecke bringen }\end{array}$ & $\begin{array}{l}\text { chasser qn. (de) } \\
\text { débusquer qn. }\end{array}$ \\
\hline $\begin{array}{l}\text { Eng } \\
\text { Ger } \\
\text { Fr } \\
\end{array}$ & $\begin{array}{l}\text { monkey } \\
\text { Affe } \\
\text { singe }\end{array}$ & monkey around & herumalbern & faire l'idiot \\
\hline $\begin{array}{l}\text { Eng } \\
\text { Ger }\end{array}$ & $\begin{array}{l}\text { pig } \\
\text { Schwein }\end{array}$ & pig out (on) & $\begin{array}{l}\text { sich den Bauch } \\
\text { vollschlagen (mit) }\end{array}$ & $\begin{array}{l}\text { se goinfrer, } \\
\text { s’empiffrer (de) }\end{array}$ \\
\hline
\end{tabular}

\footnotetext{
${ }^{3}$ The principle of redundancy avoidance is also operative in constructions with subject incorporations such as *The dog dog-paddled across the pond, ${ }^{*}$ The birds bird-chirped all morning, and ${ }^{*}$ Look, the bear is bear-hugging the trainer (see Thornburg and Panther 2000).
} 


\begin{tabular}{|c|c|c|c|c|}
\hline $\mathrm{Fr}$ & cochon & & & \\
\hline $\begin{array}{l}\text { Eng } \\
\text { Ger } \\
\text { Fr }\end{array}$ & $\begin{array}{l}\text { rat } \\
\text { Ratte } \\
\text { Rat }\end{array}$ & $\begin{array}{l}\text { rat sb. out } \\
\text { rat around }\end{array}$ & $\begin{array}{l}\text { jm. verpfeifen } \\
\text { herumlungern }\end{array}$ & $\begin{array}{l}\text { dénoncer, } \\
\text { moucharder qn. } \\
\text { glandouiller }\end{array}$ \\
\hline $\begin{array}{l}\text { Eng } \\
\text { Ger } \\
\text { Fr }\end{array}$ & $\begin{array}{l}\text { squirrel } \\
\text { Eichhörnchen } \\
\text { écurueil }\end{array}$ & squirrel sth. away & aufbewahren, einlagern & mettre qch. de côté \\
\hline $\begin{array}{l}\text { Eng } \\
\text { Ger } \\
\text { Fr } \\
\end{array}$ & $\begin{array}{l}\text { weasel } \\
\text { Wiesel } \\
\text { belette } \\
\end{array}$ & $\begin{array}{l}\text { weasel sb. out of } \\
\text { sth. } \\
\text { weasel out of sth. }\end{array}$ & $\begin{array}{l}\text { jm. etw. ablisten } \\
\text { sich drücken vor }\end{array}$ & $\begin{array}{l}\text { soutirer qch. de qn. } \\
\text { se défiler }\end{array}$ \\
\hline $\begin{array}{l}\text { Eng } \\
\text { Ger } \\
\text { Fr }\end{array}$ & $\begin{array}{l}\text { wolf } \\
\text { Wolf } \\
\text { loup }\end{array}$ & wolf down sth. & etw. hinunterschlingen & dévorer qch. \\
\hline
\end{tabular}

Interestingly, the English critter constructions in Table 1 have no literal counterparts in German and French. For example, chicken out 'lose one's courage (in the face of an enemy, or a dangerous situation)’ (Cowie and Mackin 1975) translates as kneifen (lit. 'feel a pinch') in German, and se dégonfler (lit. 'deflate oneself') in French. The only exception in the table is ferret about, which has a more or less literal counterpart in French: fureter (dans) (lit. 'ferret in').

Critter constructions thus seem to be more frequent in English than in German and French. ${ }^{4}$ It is unlikely that this skewing is caused by cultural differences, since the same or similar cultural models involving animals are available for German and French language users. We assume here that the reasons for this asymmetry between English, on the one hand, and German and French, on the other, are due to grammatical differences. English is a language with little inflectional morphology, and it allows conversion from nouns to verbs more easily than languages with richer morphology, like German and French. As is well known, conversion is an extremely productive word-formation process in English (Clark and Clark 1979, Dirven 1999).

\footnotetext{
${ }^{4}$ There are, however, German verbs derived from animal nouns that have no literal equivalents in English: e.g. büffeln (lit. 'to buffalo') 'cram', ochsen (lit. 'to ox') 'work hard', wurmen (lit. 'to worm') 'rankle'. In other words, the claim that English has more critter constructions than German must be supported by further evidence.
} 


\section{III.1. General characteristics of critter constructions}

The general conceptual schema for critter constructions that we use as a template for the discussion of individual cases is given in Figure 3.

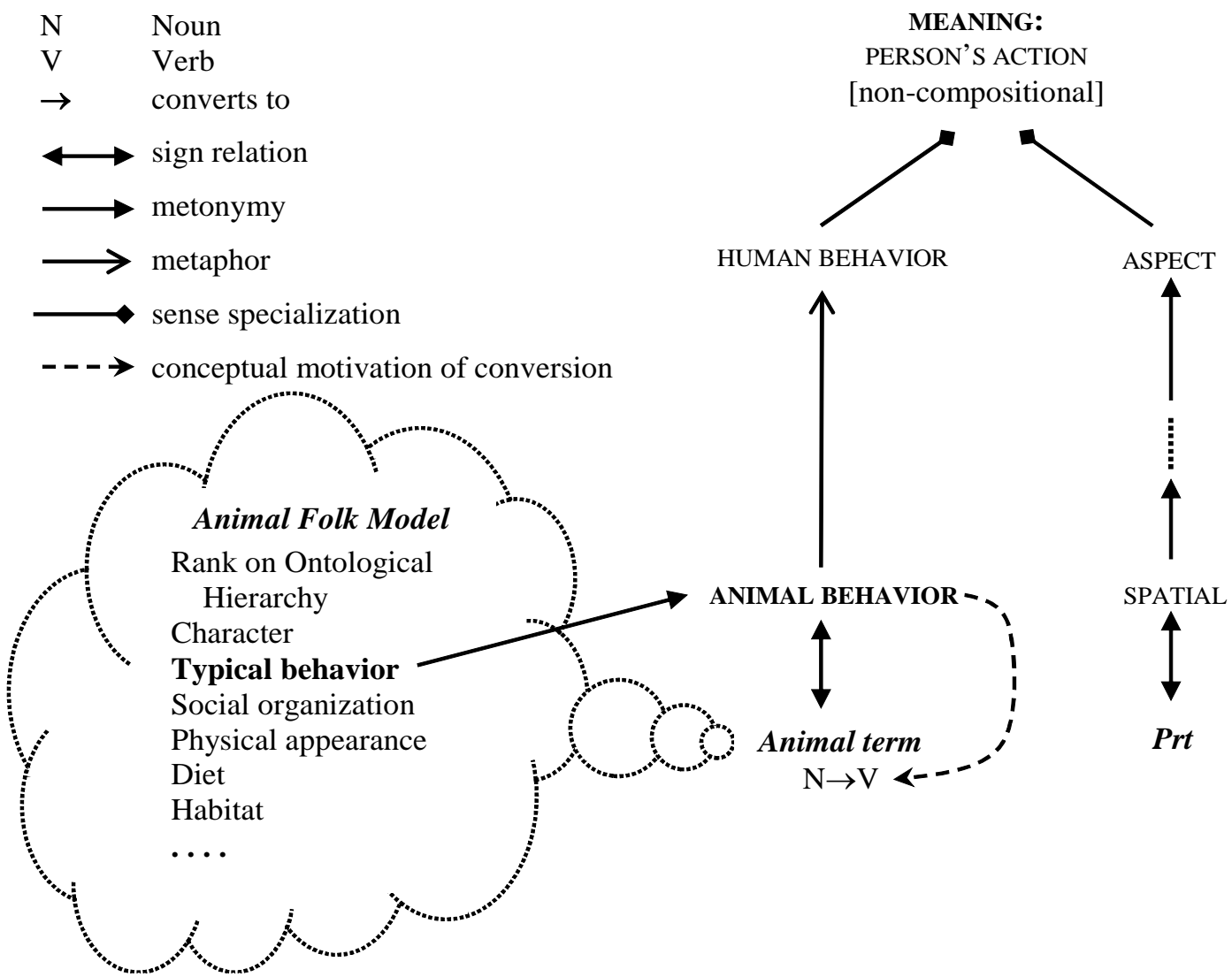

Figure 3. Conceptual schema for critter constructions.

The descriptive apparatus diagrammed in Figure 3 includes an animal folk model, i.e. more or less entrenched beliefs about animals, their character, their typical behavior, and their value on an ontological hierarchy or on the 'Great Chain of Being', in the terminology of Lakoff and Turner (1989: ch. 4). For example, one can safely assume that humans are universally higher-ranked than domesticated animals like dogs and cats, which, in turn, are higher-ranked than, say, rats and cockroaches. The ranking may however differ from culture to culture. In Western mythology, dragons are monstrous reptiles that have to be slain by valiant knights, whereas in the Chinese tradition the dragon is considered to be a friendly and benevolent animal. Rats, which are generally regarded as despicable and unclean creatures in Western culture, enjoy, according to Wikipedia, a much better reputation in China, and are endowed with mostly positive 
character traits. The rat is the first animal (of twelve) in the Chinese zodiac and "[p]eople born in [the year of the rat] are expected to possess qualities associated with rats, including creativity, intelligence, honesty, generosity, ambition, a quick temper and wastefulness." ${ }^{5}$ A final point to be made with regard to models is that, intraculturally, beliefs about animals (as about anything else) may change, and it is an interesting question if, when, and how such changes in a cultural model affect the linguistic system as such. This issue is briefly touched upon in section IV.

We assume that folk models of the sort described in the preceding paragraph feed into the semantic reading of the animal term used as a verb in critter constructions, as depicted in Figure 3. The diagram should be read from bottom to top. First, the Animal term and the Prt are linked via double-headed arrows (representing the sign relation) to their respective meanings, rendered in small capital letters. Second, the Animal term evokes a cultural model, represented by propositional information inside the 'cloud'. Third, a salient behavioral component of the folk model is selected as the crucial meaning element of the semantic representation (viz. ANIMAL BEHAVIOR). This selection process can be called metonymic because it is brought about by a WHOLE-PART operation (WHOLE ANIMAL FOLK MODEL FOR SOME ELEMENT OF THE ANIMAL FOLK MODEL). Thus the change of word class from noun to verb in critter constructions is motivated by metonymy, not by metaphor (as assumed by Deignan 2006). Fourth, the component ANIMAL BEHAVIOR is metaphorically mapped into the human domain via the metaphor HUMANS ARE ANIMALS or, more specifically, BEHAVIOR OF HUMANS IS BEHAVIOR OF ANIMALS. This metaphor is then applied to a particular situation to describe an animal-like action of a person (or group of persons).

As to the particle Prt, its source sense starts out as a spatial image schema and develops, via metonymic chaining, into an aspectual meaning (Brinton 1988: ch. 4), i.e. it determines whether the behavior denoted by the critter verb is to be interpreted as an activity, an accomplishment, or an achievement, in the terminology of Vendler (1957). We elaborate the metonymic chaining leading to the aspectual target sense of the particle in section III.2.

\footnotetext{
${ }^{5}$ Source: http://en.wikipedia.org/wiki/Rat\#In_Asian_cultures
} 
To conclude, we emphasize again that the overall meaning of a critter construction is not determined compositionally. Rather, the construction of its meaning involves an operation of ‘sense specialization', which provides for the idiosyncratic, non-predictable but motivated meaning of the verb+particle 'gestalt'. This point is taken up again in section III.2, where specific critter constructions are discussed.

\section{III.2. Three case studies}

In the following three subsections we analyze three critter constructions in more detail, by applying the template presented in Figure 3.

\section{III.2.1. Rat out}

A good starting-point for the analysis of the critter construction rat out is a cartoon from the New Yorker, shown in Figure $4 .^{6}$

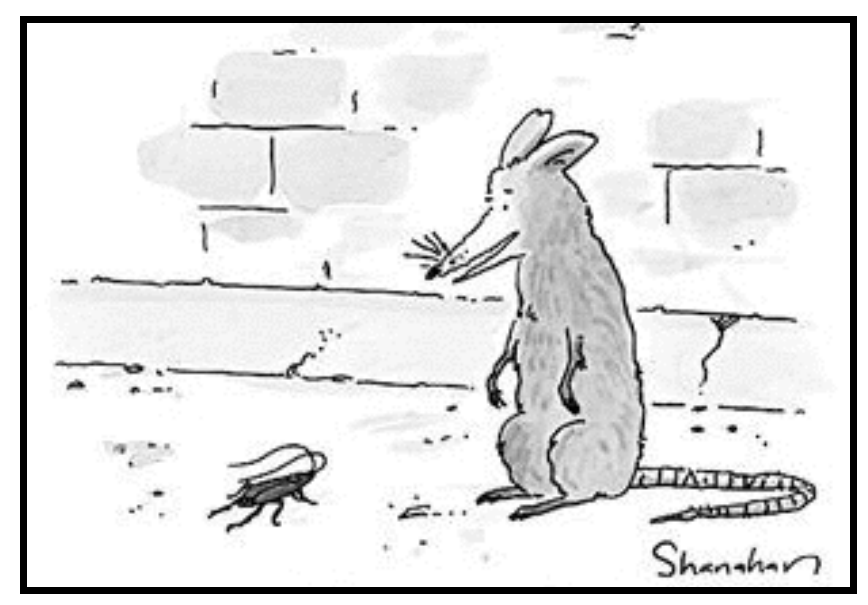

"I love your work."

Figure 4. Humor based on a negative rat model.

Animal cartoons are a rich source for the identification of underlying animal folk models because their humorous effects often rely on a stereotypical conception of the animal in question. In Figure 4, one despicable animal, the rat, addresses perhaps an

\footnotetext{
${ }^{6}$ Source: gc.allpostersimages.com/images/P-473-488-90/60/6010/6J5B100Z/posters/ danny-shanahan-ilove-your-work--new-yorker-cartoon.jpg
} 
even more despised critter, a cockroach, praising its 'work'. Both critters have traditionally been ranked very low on the Great Chain of Being.

With respect to the particle verb rat out 'inform on', it comes as no surprise that its meaning is pejorative; morally reprehensible actions such as informing on somebody are committed by morally depraved persons - and rats are believed to embody vile character and behavioral traits. The description of such vile actions as rat out is therefore highly motivated (although not predictable; see section III.1).

Figure 5 diagrams the conceptual structure of rat out.

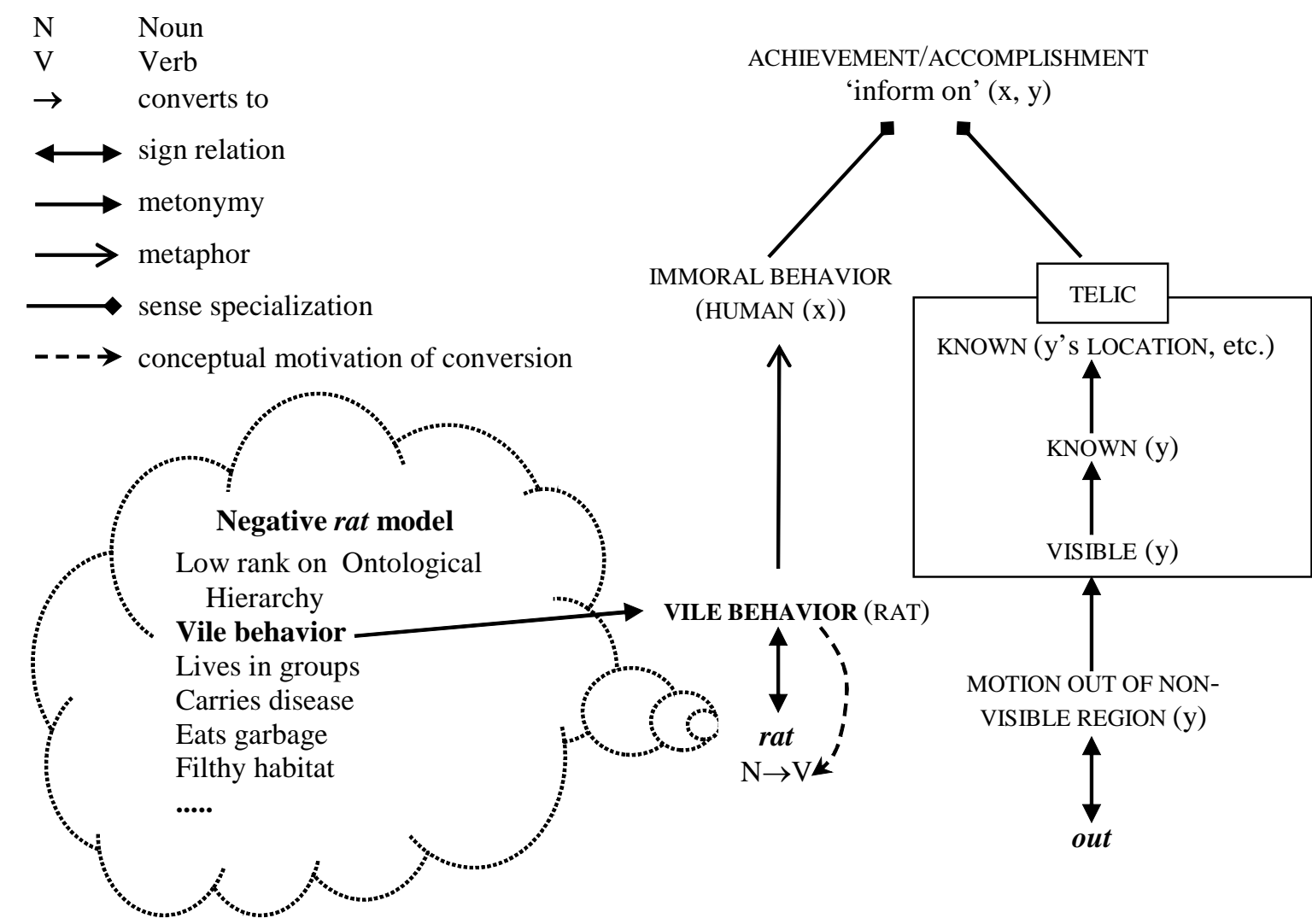

Figure 5. Conceptual structure of rat out.

The analysis of rat out proposed in Figure 5 reads as follows. We begin with the meaning contribution of rat. The relevant component of the rat model for the interpretation of rat is the attribute VILE BEHAVIOR. This negative rat attribute is metaphorically mapped onto the human property IMMORAL BEHAVIOR. The final operation (sense specialization) narrows down the general sense IMMORAL BEHAVIOR OF A HUMAN to the specific immoral action of INFORMING ON some fellow human. 
The spatial source sense of the particle out contributes an aspectual value to the overall meaning of rat out via a series of metonymies. In its source sense, out designates the motion of some object $y$ (here, the patient $y$ ) from a non-visible region into a region where $y$ can be seen by some third party; VISIBILITY of $y$ is then, via metonymic inference, linked to KNOWLEDGE about $y$; and finally, there is an inference from KNOWN (y) to KNOWN (y's LOCATION, INTENTIONS, etc.), i.e. the patient's location, plans, etc. are revealed to some third party by the informer $x .^{7}$

The final product of the above metaphoric and metonymic mechanisms is a specialized idiosyncratic meaning. The particle out contributes to the construction a telic aspect and the aspectual meaning ACHIEVEMENT or ACCOMPLISHMENT. ${ }^{8}$ The specific verbal meaning 'betraying someone by informing a third party on someone's location, plans, etc.' is motivated by the vile and morally depraved behavior of the informer, but is not strictly predictable from the cultural model of rats.

Note that what is coded in the critter construction rat out is one salient negative aspect of the rat model. But, in fact, in other constructions rat can also have a more positive connotation, e.g. in compounds such as rugrat 'toddler, child crawling on the floor', which evokes a potentially more endearing model of rats than the one conveyed by rat out. We return to this point in section IV.

\section{III.2.2. Beaver away}

The critter construction beaver away evokes a folk model of beavers as industrious, hard-working animals. The cartoon in Figure 6 presupposes such a model and exploits it for humorous purposes.

\footnotetext{
${ }^{7}$ As proposed by various scholars, e.g. Barcelona (2000), Radden (2002), Panther (2006), the relation between VISIBILITY and KNOWLEDGE is basically metonymic rather than metaphoric (as assumed by Sweetser 1990: 37-40).

${ }^{8}$ Rat out can be used as an achievement in sentences like At midnight he ratted out his accomplices (punctual interpretation) or as an accomplishment in Within three days he ratted out all his accomplices.
} 


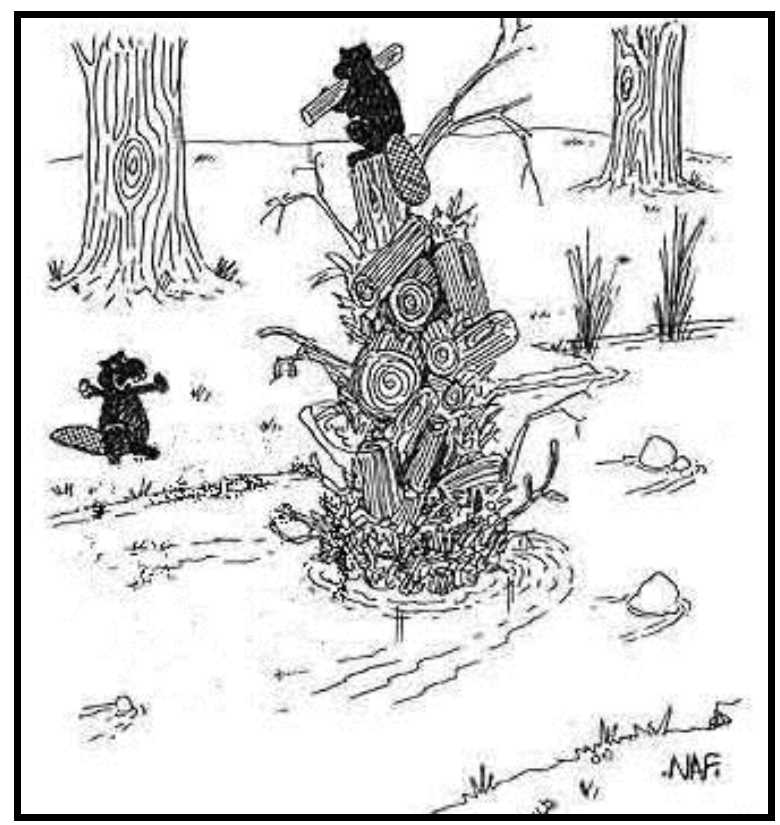

"Not up the way, you idiot, across the way!" Figure 6. The industrious (but stupid) beaver.

The conceptual structure of beaver away is diagrammed in Figure 7.

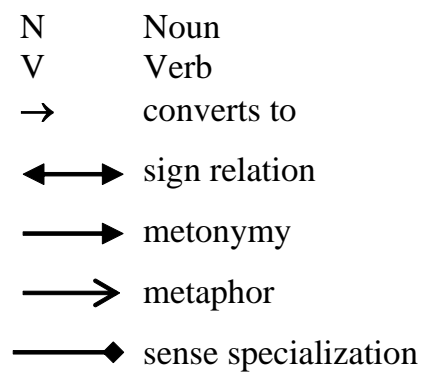

$>--\rightarrow$ conceptual motivation of conversion

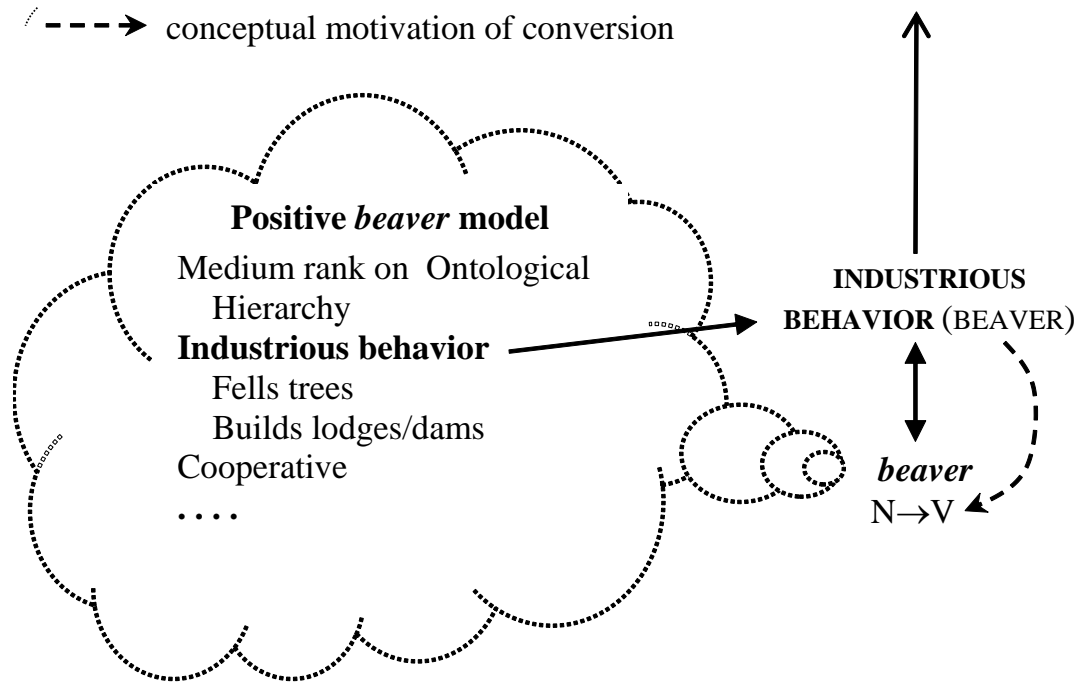

Figure 7. Conceptual structure of beaver away.
ACTIVITY

WORK HARD (x)

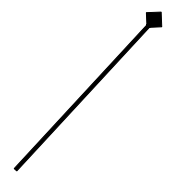

INDUSTRIOUS

BEHAVIOR (HUMAN (x))

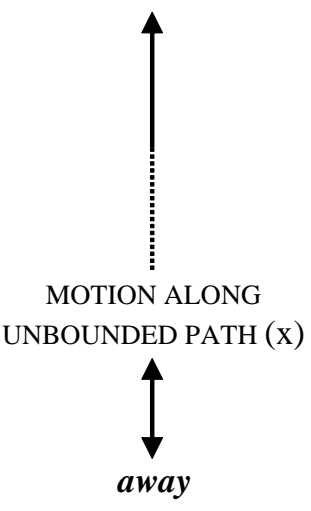


The feature selected from the beaver model in beaver away is INDUSTRIOUS BEHAVIOR, which is metaphorically mapped into the human domain and used to conceptualize the human activity of working hard. The particle away marks the aspect of the event coded by beaver as DURATIVE. How is it possible for away to code the durative aspect? We propose that it has a dynamic meaning, evoking the motion of some $x$ (the agent of the activity) along an unbounded path. In Figure 7 we again interpret the relationship between the spatial particle, in this case away, and its aspectual target meaning as metonymic. In other words, the movement of an object along a path invites the metonymic inference of (unbounded) temporal extension. An alternative way of interpreting the relation between the source and target sense of away would be to regard it as a metaphor that establishes correspondences between the movement of $x$ along an unbounded path and an unbounded activity of $x$. In our view, however, conceptual metonymy is the more basic cognitive mechanism to account for the relationship between source and target meanings of away in beaver away. Given our knowledge of the world, we have an immediate spontaneous association between the motion of an object along a trajectory and its temporal extension. This associative linking is a typically metonymic process (see Figure 2).

\section{III.2.3. Clam up}

The folk model of clams that is relevant to the source meaning of clam up is nicely illustrated by the cartoon in Figure 8: 


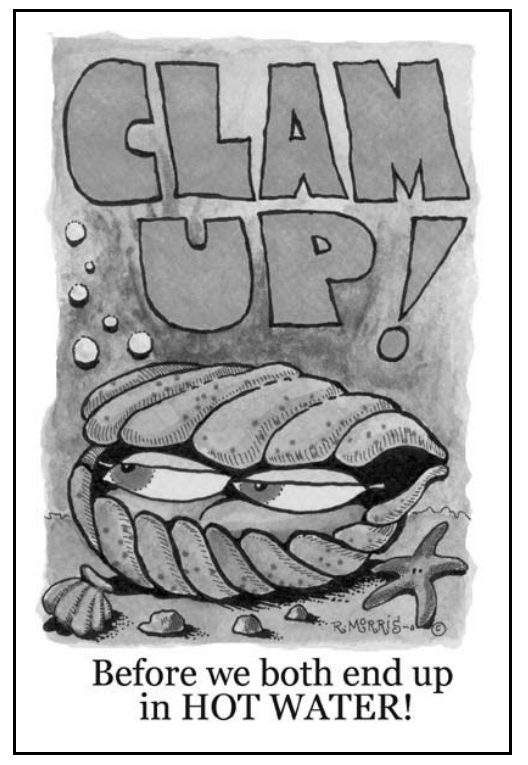

Figure 8. Clam issuing a warning to take protective action (i.e. close shells).

The target sense of clam up, i.e. 'abruptly stop talking', is diagrammed in Figure 9.
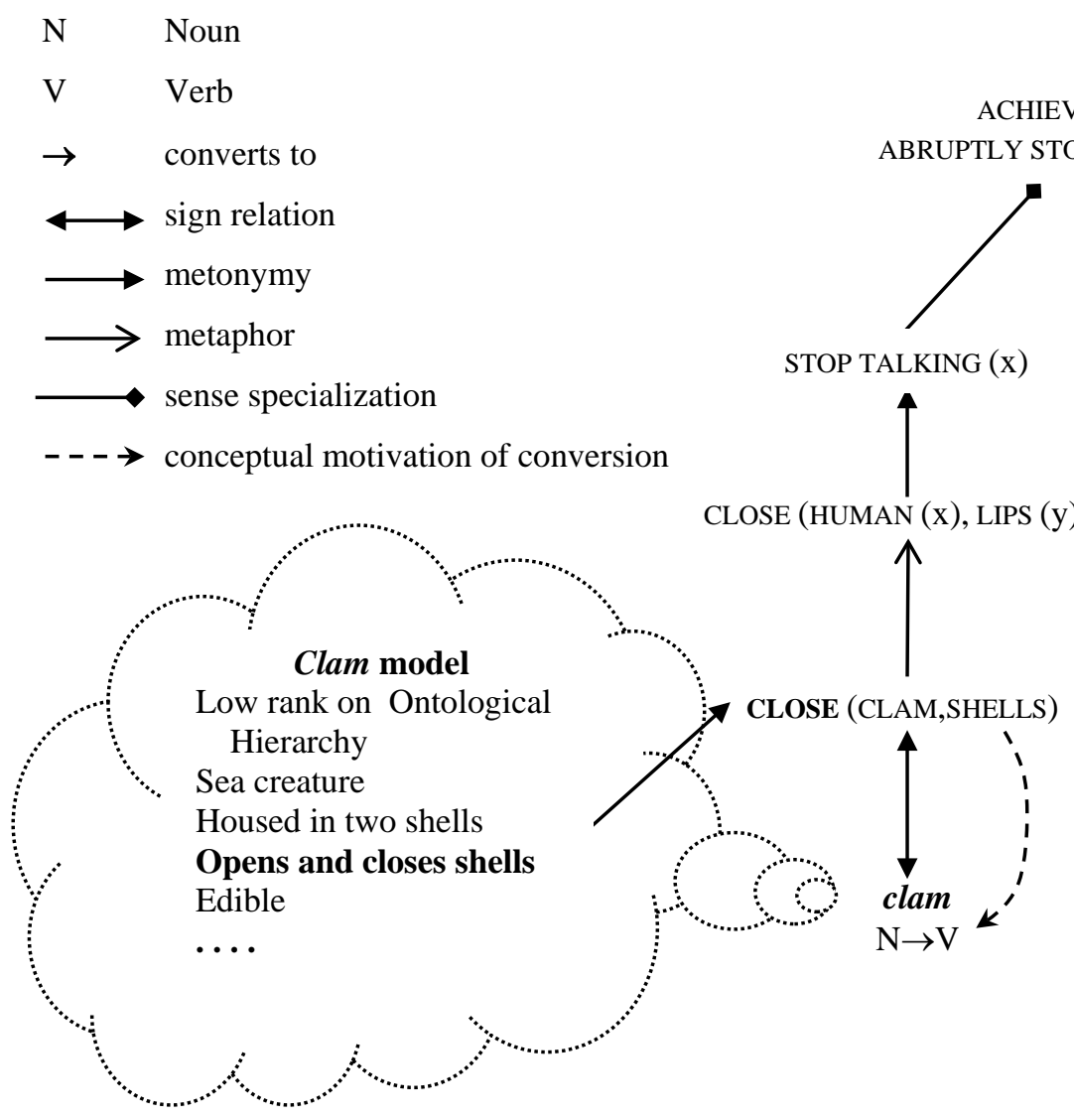

Figure 9. Conceptual structure of clam up. 
Being a bivalve mollusk, the clam is presumably low on the ontological hierarchy; however, unlike rats and cockroaches, it is not associated with any particular negative attributes. The feature in the folk model that has become conventionalized in clam up is the capability of clams to close their shells instantaneously when under threat, and it is this attribute that is likened to the action of a person suddenly closing his or her lips. This action stands metonymically for 'stop talking' or 'falling silent'. The aspectual meaning of clam up is contributed by the particle up, which evokes vertical movement (of $x$ ) toward a completion point (marked as TELIC in Figure 9). Since clam up is conventionally interpreted as 'abruptly stop talking', it has the aspectual feature PUNCTUAL, which accounts for its ACHIEVEMENT sense or, more generally, perfective meaning. The punctual aspect of clam up is depicted in detail in Figure 10.

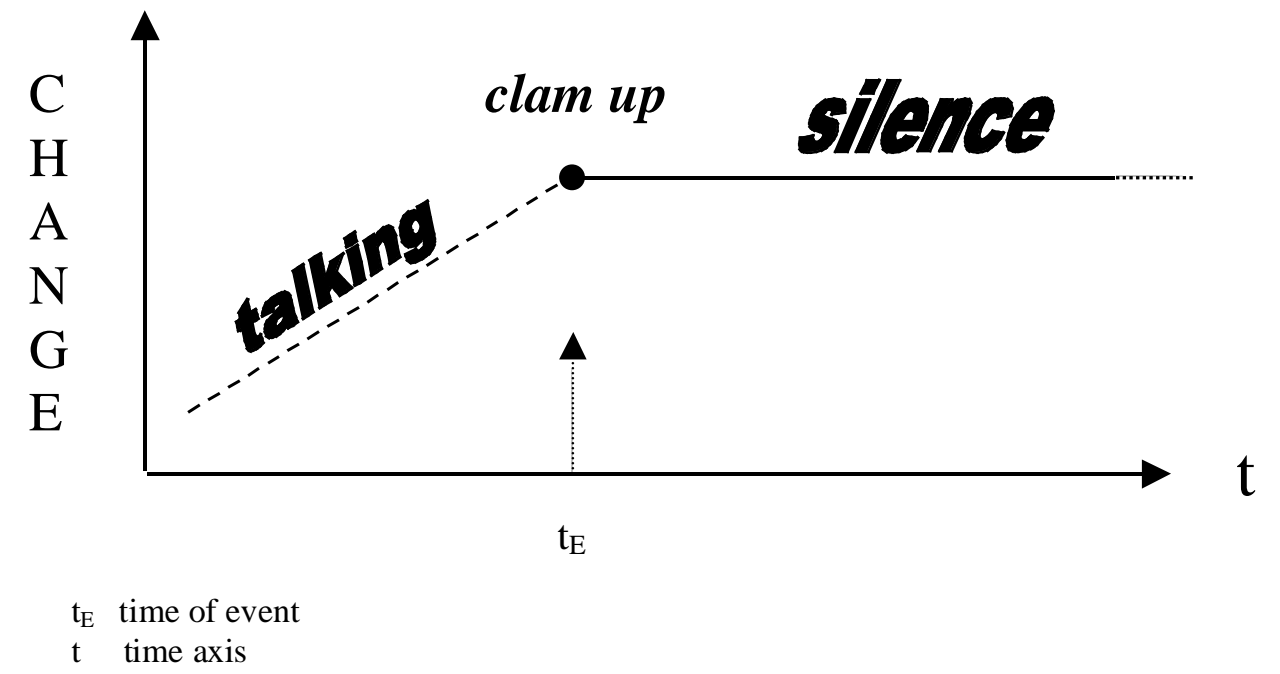

Figure 10. Punctual aspect of clam up.

In Figure 10, the sloped dashed line represents a backgrounded (or presupposed) phase of the clam up event, namely talking. The large dot marks the moment $\left(\mathrm{t}_{\mathrm{E}}\right)$ at which talking ceases. It is this point of change that is actually coded by the expression clam up. After this culmination point, a state of silence ensues, which is marked in Figure 10 by an indefinitely extended horizontal line. 


\section{CONCLUSIONS}

In this chapter we have shown that the meanings of the converted animal terms in critter constructions are not predictable, but are motivated by animal folk models. One behavioral component of an animal folk model is metonymically selected and metaphorically projected into the human domain as HUMAN BEHAVIOR. Thus the change of word class $(\mathrm{N} \rightarrow \mathrm{V})$ in critter constructions is motivated by metonymy, not by metaphor.

The particle in critter constructions has an aspectual value, e.g. TELIC, DURATIVE, or PUNCTUAL. It is derivable via metonymic inference(s) from a spatial image schema. The aspectual value of the particle thus motivates the lexical aspect of the whole critter construction as ACTIVITY, ACHIEVEMENT, or ACCOMPLISHMENT, for example.

The folk models that are evoked by VPrt critter constructions (at least the ones investigated herein) appear to be extremely conservative. They are susceptible to 'cultural lag', that is, they are neither immediately influenced by new scientific insights nor by innovative cultural developments leading to changes in the attitudes toward animals. To limit our discussion to just one example, rats could plausibly be characterized as very industrious (just like beavers) and one might expect that rat away could mean, in some contexts, 'work industriously'. Although one could argue that rat away is 'blocked' by the pre-existing beaver away, that does not preclude the possibility that there exists another blocking factor, namely the negative cultural model of rats. Likewise, scientific models of rats characterize these rodents as being smart and resourceful, in fact capable of finding their way out of complicated mazes. Given that many educated speakers are most likely familiar with such studies popularized in the media, one might expect that sooner or later the linguistic community would coin the expression rat one's way out meaning 'find a solution to a difficult problem', which in fact has not happened. Likewise, the creation of a related particle+verb expression outrat in the sense of 'outfox' or 'outsmart' seems to be highly unlikely. In its usage as a verb, the semantics of rat seems to be constrained by the negative folk model discussed in section III.2.1.

Yet, as also noted in section III.2.1, constructions other than the VPrt critter construction - specifically, compounds with rat(s) functioning as the morphological 
head in the previously mentioned rugrats ('toddlers/young children who play on the floor') - seem to be a linguistic vehicle through which a less negative image of rats may be conveyed. Similar neologisms are mallrats ('adolescents/teenagers hanging out at the mall' and sprawlrats ('college students who share suburban housing'). In its function as the head in compounds, rat(s) evokes the social organization of rats (living in groups) while the modifier (rug, mall, and sprawl - 'sprawling suburban neighborhood') references the habitat where the metaphorized 'rats' spend large amounts of their time. 'Group' and 'habitat' per se are relatively neutral meaning components in these compounds despite their origin in the rat model. In contrast, when rat functions as a modifier in compounds, e.g. rat-infested, rat-hole ('squalid habitat/hiding place'), rat race ('fiercely competitive struggle for wealth/power'), and rat bag (Br. 'unpleasant/disliked person'), to name but a few, extremely negative components of the rat model, like 'squalid', 'vile, 'diseased', and 'fiercely combative', are evoked. These observations show that different types of grammatical constructions containing rat as a noun or verb interact differentially with the rat folk model (see also the discussion of sentences (1)-(5) in section II). Exploring this question would constitute an interesting line of research.

In general, however, we hypothesize that linguistic codings have a tendency to 'freeze' cultural models, sometimes from centuries past, and thus quite often reflect outdated worldviews and theories - including biological models. In contrast, in other semiotic systems, e.g. the visual arts, new cultural models may be adopted and implemented more readily than in the language system. To see this, consider Figure 11, which shows a lab rat 'out of work'. 


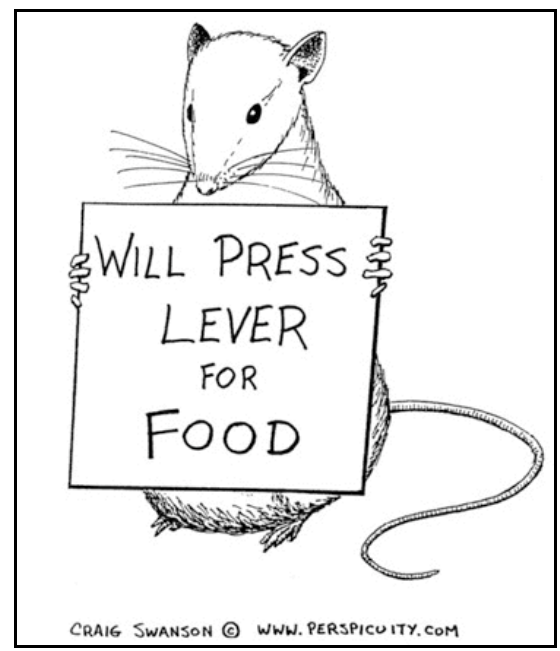

Figure 11. A empathetic rat model.

The rat image in Figure 11, a Beatrix Potter-like depiction of the animal, empathetically represents a situation with which humans, in a period of economic stress, can readily identify. The cartoon captures an aspect of the $21^{\text {st }}$ century human condition (the desperate search by many people for any kind of work, even if it is inhumane, unpaid, and humiliating) and, in so doing, stands the centuries-old folk model of rats on its head.

\section{REFERENCES}

Barcelona, A. 2000. "On the plausibility of claiming a metonymic motivation for conceptual metaphor”. In Barcelona, A. (Ed.) Metaphor and Metonymy at the Crossroads: A Cognitive Perspective. Berlin/New York: Mouton de Gruyter, 3158.

Bridoux, A. (Ed.) 1953. Oeuvres et lettres de Descartes. Paris: Gallimard.

Brinton, L.J. 1988. The Development of English Aspectual Systems. Cambridge: Cambridge University Press.

Clark, E.V. and Clark, H.H. 1979. "When nouns surface as verbs”. Language 55, 767-811. 
Deignan, A. 2006. “The grammar of linguistic metaphors”. In Stefanowitsch, A. and S.T. Gries (Eds.) Corpus-Based Approaches to Metaphor and Metonymy. Berlin/ New York: Mouton de Gruyter, 106-122.

Dirven, R. 1999. "Conversion as a conceptual metonymy of event schemata”. In Panther, K.-U. and G. Radden (Eds.) Metonymy in Language and Thought, Amsterdam/Philadelphia: John Benjamins, 275-287.

Drabble, M. (Ed.) 2000. The Oxford Companion to English Literature. Oxford/New York: Oxford University Press.

Goatly, A. 2006. "Humans, animals, and metaphors”. Society and Animals 14 (1), 1537.

Lakoff, G. and Turner, M. 1989. More than Cool Reason: A Field Guide to Poetic Metaphor. Chicago: The University of Chicago Press.

Longman Dictionary of American English (LDAE). 1983. White Plains, NY: Longman.

New Oxford American Dictionary. 2010. Stevenson, A. and C.A. Lindberg (Eds.). Oxford: Oxford University Press.

Oxford Dictionary of Current Idiomatic English. Vol. 1: Prepositions \& Particles. 1975. Cowie A.P. and R. Mackin (Eds.). London: Oxford University Press.

Panther, K.-U. 2006. “Metonymy as a usage event”. In Kristiansen, G., M. Achard, R. Dirven, and F.J. Ruiz de Mendoza Ibáñez (Eds.) Cognitive Linguistics: Current Applications and Future Perspectives. Berlin/New York: Mouton de Gruyter, 147-185.

Panther, K.-U. and Radden, G. 2011. "Introduction: Reflections on motivation revisited”. In Panther, K.-U. and G. Radden (Eds.) Motivation in Grammar and the Lexicon. Amsterdam/Philadelphia: John Benjamins, 1-26.

Quinn, N. and Holland, D. 1987. “Culture and Cognition”. In Holland. D. and N. Quinn (Eds.) Cultural Models in Language and Thought. Cambridge: Cambridge University Press, 3-40. 
Radden, G. 2002. “How metonymic are metaphors?”. In Dirven, R. and R. Pörings (Eds.) Metaphor in Comparison and Contrast. Berlin/New York: Mouton de Gruyter, 407-434.

Ris-Eberle, S. 2004. “Tiere in der Religion Ägyptens: Tiere als Götter im Alten Ägypten?” UniPress 122. Bern: Universität Bern, Abteilung Kommunikation, 5053.

Sweetser, E.E. 1990. From Etymology to Pragmatics: Metaphorical and Cultural Aspects of Semantic Structure. Cambridge: Cambridge University Press.

Thornburg, L.L. and Panther, K.-U. 2000. "Why we subject incorporate (in English): A post-Whorfian view”. In Pütz, M. and M.H. Verspoor (Eds.) Explorations in Linguistic Relativity. Amsterdam/Philadelphia: John Benjamins, 319-343.

Vendler, Z. 1957. "Verbs and times”. The Philosophical Review 66, 143-160.

Received: 05 February 2012

Accepted: 04 March 2012

Cite this article as:

Panther, K.-U. and Thornburg, L.L. 2012. "Conceptualizing humans as animals in English verb particle constructions”. Language Value 4 (1), 63-83. Jaume I University ePress: Castelló, Spain. http://www.e-revistes.uji.es/languagevalue. DOI: http://dx.doi.org/10.6035/LanguageV.2012.4.4

ISSN 1989-7103

Articles are copyrighted by their respective authors 